NBER WORKING PAPER SERIES

\title{
A MULTINOMINAL LOGISTIC APPROACH TO THE LABOR FORCE BEHAVIOR OF JAPANESE MARRIED WOMEN
}

\author{
Tadashi Yamada \\ Tetsuji Yamada \\ Frank Cha loupka
}

Working Paper No. 1783

\section{NATIONAL BUREAU OF ECONOMIC RESEARCH 1050 Massachusetts Avenue Cambridge, MA 02138 \\ December 1985}

\footnotetext{
The research reported here is part of the NBER's research program in Labor studies. Any opinions expressed are those of the authors and not those of the National Bureau of Economic Research.
} 
NBER Working Paper \#1783

December 1985

A Multinominal Logistic Approach to the Labor Force Behavior of Japanese Married Women

\begin{abstract}
Using a multinomial logistic approach, we analyze the interdependencies among the labor force participation decisions of married women in Japan. These decisions are working part-time, working full-tlme, being unemployed (in the labor market but unable to find work), and not participating. Our focus as on the interdependency between the decision to work part-time and the decision to work full-time. Our results indlcate that married women working full-time view part-time work as a good substitute, but the reverse is not observed. We also obtann estimates of the own-wage elasticity for both forms of participation and find that part-time labor force particicipatzon of Japanese married women is substantially more elastic than that of their full-time counterparts. These findings reinforce the view that marraed women in Japan with loose ties to the labor market are quite responsive to changes in the returns to work.
\end{abstract}

Tadashi Yamada NBER 269 Mercer Street 8th Floor New York, NY 10003
Tetsuji Yamada Dept. of Economics Graduate School and University Center of CUNY New York, NY 10036
Frank Chaloupka NBER

269 Mercer Street

8th Floor

New York, NY 10003 
A Multanomal Logastac Approach to the Labor Force behavior. of Japanese Marrzed Women ${ }^{*}$

I adashl Yamada, I'etsujz Yamada, and Frank Chaloupka

\section{Introduction}

Recent contrabutions from Hzll (1983, 1984) and Shamada and Haguch ( 1985 ) have made sagnaficant changes in the analysas of female labor force behavior an Japan. These studies specifically focus on female employees in the labor market by asolatang selfemployed and family workers an the intormal sector. These recent results showed a posatzve effect of wages on labor force par-

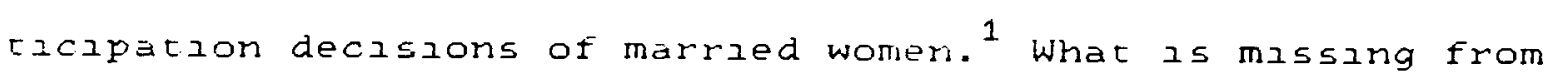
thenr analyses as a systemitac examanatzon of the behavior of marrzed women who choose to work oniy part-tzme, accounting for approximately half of the marrzed women in urban Japan accordang to the 1980 Fopulatzon Census of Japan. As studzes usang Unzted States and Canadian data have shown, the response of part-tame workang married women to changes an the returns to work as quate different from that of thear full-tame counterparts (for example, Norgenstern and Hamovitch 1976; Long and Jones 1980; Nakamura and Makamura 1983). The Increasung zmportance of part-tame workang

\footnotetext{
* We are indebtea to Machael Grossman, Bernard ukun, and Foban Carey for their helpful coments or the farst draft of thas paper. The opinions expresied in tha forer, as well as ary irrors are, of course, ours.

Early studies of the labur force bohavor of Japanese women can be found an Hamiton (19/4), Furugora (1980), Nagano (1980), and Enzmada, et al. (1981). They had a major drawback in that they

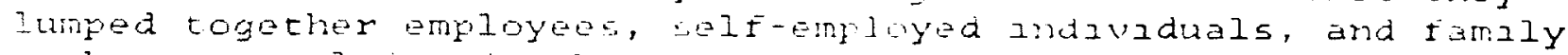
workers, resulting in the or oberved negatave effect of women's :ages on labor force pertacifataon, : hgestang a backward bendang iabor supply curve.
} 
married women in Japan can no longer be lgnored.

In thas paper, we anvestagate the anterdependency of four alternatave labor force partacipation statuses using a multanompal logistzc approach. The four mutually exclusive and exhaustuve labor force participation decisions are working full-time, working part-tıme, unemployment, and not partacipating. by azstungulshung among the particupation decisions we can obtann separate estimates of the own-wage elastlcity of marryed women working part-tzme and full-tame, and also identafy interdepedencies through thezr cross-wage elastacities.

The organzation of the subsequent sections is as follows: Section II outlunes the model and our a-priorl expectations of the effects of the varuables in the model on labor force participation behavior, section III reports the emplrical results, and, funally, Section IV gives our conclusions. 


\section{Methed ef Bnalysis}

The variables $1 n$ our model are cross-sectional market averages primarily drawn from the 1980 population Census of Japan. The units of observation are the urban areas of the 47 prefectures of Japan. The advantages of using cross-sectional market averages, as discussed by Cann and Dooley (1976) and Lnnk and Settle (1981), are that varnations in tastes and transitory wages within a given geographical area can be averaged out. By differentiating married women whose spouses are present from other women, distinguishing urban Japan from rural Japan, and separating full-time and part-time work decisions, our sample represents a relatively homogeneous group of married women, resulting in consistent estimates of the structural parameters. Our multinomial logistic approach assumes that a married woman faces four mutually exclusive alternatives wath the corresponding probablinties $P_{1}, P_{2}, P_{3}$, and $P_{4}$, whlch represent the probability that the woman chooses full-tame work, part-tame work, unemployment, or non-particlpation, respectively. BY definition, the sum of the probabilitaes is equal to one. The logistic probability function is:

$$
\begin{aligned}
& P_{I}=\left[\exp \left(\alpha_{I}+\Sigma_{J}\left(\beta_{I} K_{j}\right)\right) /\left(1+\Sigma_{I} \exp \left(\alpha_{I}+\Sigma_{\jmath}\left(\beta_{I} X_{j}\right)\right)\right)\right] \\
& 1=1,2,3
\end{aligned}
$$

and:

$$
p_{4}=\left[1 /\left(1+\Sigma_{1} \exp \left(\alpha_{i}+\Sigma_{j}\left(\beta_{2 j} K_{j}\right)\right)\right)\right]
$$

\footnotetext{
Further insight into the part-cime labor supply decisions of Japanese married women awalts the avallablizty of individual and longitudinal data. See Dooley (1982) for arguments ln favor of using micro data in place of aggregate cross-sectional data.
} 
where the $K, J=1, \ldots, m$, are the Independent variables.

By solving for the log-odds ratio of the $2^{\text {th }}$ type of participation decision ( $p_{1}$ relative to $p_{4}$ ), the logistic equation can be expressed in the Iinear form:

$$
\ln \left(p_{1} / p_{4}\right)=\alpha_{1}+\Sigma\left(\beta_{1} K_{J}\right), 1=1,2,3 \text {. }
$$

The marginal effect of $X_{3}$ on $p_{1}$ ls obtalned from:

$$
\left(\partial p_{I} / \partial K_{J}\right)=\beta_{I J} p_{I}-p_{I} \Sigma_{I}\left(\beta_{I J} p_{I}\right), \quad I=1,2,3 \text {. }
$$

and:

$$
\left(\partial p_{4} / \partial X_{j}\right)=-\Sigma_{2}\left(\partial p_{2} / \partial X_{j}\right) .
$$

In our model, the $p_{1}$ are unobserved and constranned to the interval from zero to one. For the estimation of equation ( 3 ), we substztute $p_{f}$ (the proportion of married women, spouse present, ages 15 and older who are full-time partlclpants in the labor market) for $P_{1} ; P_{P}$ (the proportion of those women who are parttume participants) for $p_{2} ; p_{u}$ (the proportion of unemployed married women) for $p_{3} ;$ and $p_{n}$ (the proportion of those women who are non-participants) for $\mathrm{P}_{4}$.

Our theoretical framework suggests that the following variables are important in analyzing the interdependency among $P_{f}$, $P_{p}, P_{u}$, and $P_{n}$ : full-time women's wages, part-time women's wages, men's wages, the unemployment rate, women's education, the enroliment of pre-school chuldren in elther nurseries or day-care centers, and the proportion of employment an manufacturing and whoiesele and retall trade. ${ }^{3}$

Based on economic theory and on the empirical research of others on the labor force behavior of married women, we have the

\footnotetext{
The complete definitions of the variables, their sources, and statistlcs are avaliable on request.
} 
following expectations about the effects of the andependent varzables.

1.) Full-time women's wages have a positive effect on fulltime participation and a negative effect on part-time participation because married women may substitute full-time work for part-time work as the relative wage for full-time work rises.

2.) Part-time women's wages have a negative effect on fulltime participation and a posituve effect on part-time partacipation for reasons similar to those stated in 1 .

3.) Men's wages have a negatıve effect on both full-tıme and part-time participation because of the Income effect (KIllingsworth 1983).

4.) The unemployment rate can have elther positive or negative effects on any measure of participation depending on whether the added worker or discouraged worker effect dominates (Furugorl 1980; Shzmada and Higuchi 1985).

5.) Women's education can also have elther positive or negative effects. If, as they acquire more education, women's reservation wages increase, the effect will be negative (Long and Jones 1980). On the other hand, higher levels of education may reflect a taste for work analor access to jobs with nompecuniary benefits, resulting in a positive efiect (Caln and Dooley 1976).

6.) The proportion of pre-school chlldren in nurseries and day-care centers has a positive effect on all participation declsions since married women with pre-school children can substztute the use of nurseries and day-cire centers for the time inputs in child-rearing (Schult: 1978).

7.) The proportion of employmont in manufacturing and 
wholesale and retall trade has a posztzve effect on any partacapation measure, reflectang andutraes whach heavily employ women (Japan 1982, 1984). 


\section{Empirical Besults}

Using a multinomial logistic approach, we estimate a model of the labor force participation decisions of Japanese married women, using data from the 1980 Population Census for the urban areas of the 47 prefectures of Japan. The parameter estimates are given in Table 1 , and the marginal effects of the Independent variables and their estimated elasticities calculated at the sample means are reported in Table 2 .

Full-time women's wages have a statistlcally slgnificant coefficient in the full-time equation ( $I n\left(p_{f} / p_{n}\right)$ dependent) and in the unemployment equation $\left(\ln \left(\mathrm{p}_{\mathrm{u}} / \mathrm{p}_{\mathrm{n}}\right)\right.$ dependent), but are not significant in the part-time equation ( $I n\left(p_{p} / p_{n}\right.$ ) dependent). 4 The sign of the marginal effect is not directly obtalned from the sign of the estimated logit coefficient, but from the application of equations (4) and (5) of Section II. The sagns of the marglnal effects of full-time wages, positive for full-time particlpation and negative for part time participation, are as expected. The positive marginal effect on unemployed partucipants and the negative effect on non-participants shows movement into the labor force of women attracted by a relatively higher wage but who were unable to find work.

Our estimated own-wage elasticity for full-time particlpation 150.15 . Hill (1984), using 1970 Japanese Population Census data, found this elasticity to be 0.44 for all women, large

${ }^{4}$ Each equation in this study is estimated usang the generalized least squares method so as to correct for heteroscedasficty. The welghts used are: Weight
( Thell 1971 , ( Total Married Women) $\left.\left.p_{2} p_{n}\right)^{1}, 635\right)$, $1=f, p, u$ 
relative to our estimate as a result of the lumping together of full-time and part-time, single and married women. Shimada and Higuchl (1985), using cross-sectional micro data for 1977, estimated owm-wage elasticities in the range 0.04 to 0.22 for married women ages 35 and older, results whlch are comparable to ours. Lookzng at U.S. and Caradian studies, we find that our estimate is similar to the 0.27 estimate for full-time U.S. marrled women (those whose average weekly hours exceed 32 ) of Morgenstern and Hamovitch (1976), but is significantly different from that of Nakamura and Nakamura (1983) whose estimates for U.S. and Canadian full tyme working married women (those whose annual hours of work are greater than or equal to 1,400 ) range from -0.03 to -0.09

The coefficlent of part-time women's wages is statistically significant in both the full-time and the part-time equations, but 1 s not in the unemployment equation. The marginal effect of part-time wages on the probability of part-time participation is positive as hypothesized. The strong negative marginal effect of the part-time wage on the full-time particlpation probability is Indicative of movement from full-time work to part-time work as the relative part-time wage rises.

There are no related studies of Japanese women's part-time lakor participation for us to compare our results to, however there have been some done using U.S. data. Our estimated own-wage elestacity for part-tame married women's labor participation in Ja: $\equiv n$ is 0.79 , as compared with estimates of 0.25 and 0.55 rey jreted by Lorg and Jones (1980) and Morgenstern and Hamovitch (is76), respectavely. The 
the omission of a full-time women's wage varzable from thelr part-tame labor supply regressions producing estimates which are biased downwards. 5 Also, Japanese married women are more loosely attached to the labor market, putting household work ahead of part-time work.

Men's wages have a statistically sagnificant coefficient in all three equations, and the marginal effect ls negative in all three, as anticipated. Our men's wage elasticities are -0.62 and -0.51 for full-time and part-time marrled women's participation decisions, respectively. These are simplar to the estymates found by Hill (1984) of -0.52 , Nagano (1980) in the range -0.38 to -0.72 , Shimada et al. (1981) in the range -0.02 to -0.31 , and Shimada and Higuch (1985) In the range -0.02 to -0.40 leading to the conclusion that women's labor force participation is inelastIc with respect to men's wages.

The two most conslstently signjflcant varlables in the three equations are the unemployment rate and the proportion of chilaren in nurseries and day-care centers. The negative marginal effect of the unemployment rate on the prokabilities of full-time and part-time participation reflects the dominance of the discouraged worker effect over the added worker effect, supporting the earlier findings of Furligori (1980) and Shimada and Higuchi (1985). The strong positave effect of the nursery/day-care variable on any farticipation decision indacates that greater avellakllaty of these faclities enables inarrled women to sub-

\footnotetext{
The omission of a full-tine women's wage variable would cause the estimated coerficient on the part-time women's wage variable to be kiased downuards. This happens at a rase an the relative full-time wage results in the substititution of full-tame work for part-time work, if the two wages are positively correlated.
} 


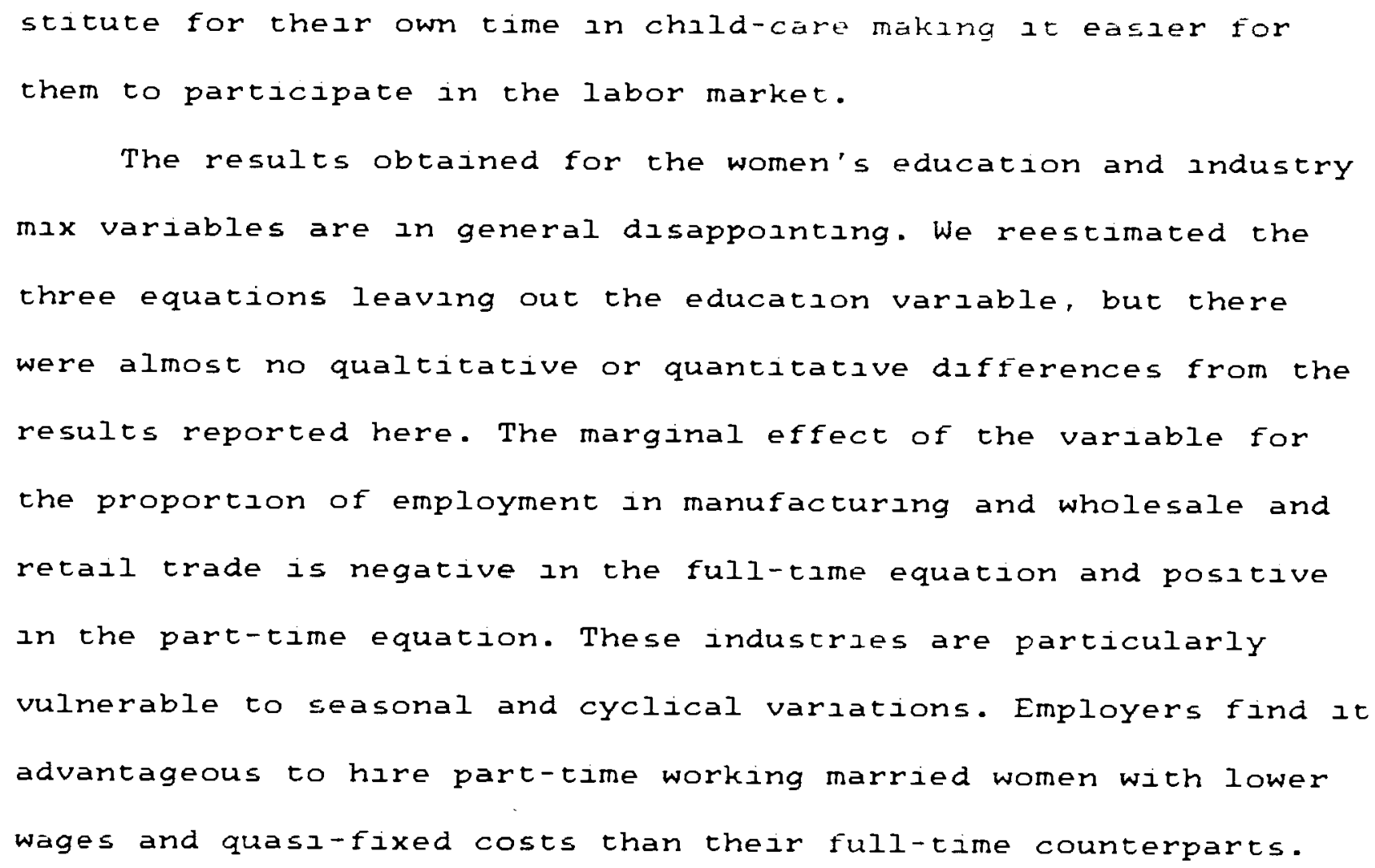




\section{Conclusions}

Our major interest in this study was the interdependency among the labor force participation decisions of Japanese married women, particularly between the decisions to work part-time and full-time. Based on our multinomial loglstac approach, we can conclude that full-time working married women view working parttime as a good substitute, but the reverse as not watnessed. A possible reason for this is that full-time work requires a much stronger commitment to the labor market that married part-tame participants are unwillang to make even at higher wages. We also find a major difference between the own-wage elasticities of part-time and full-time working married women. The estimate for the former is substantlally hagher than that for the latter, while both estimates are positive. These findings reanforce the view that Japanese married women with loose attachments to the labor market are quite responsive to changes in the returns to work. 
TABLE 1

Emplrical Results ${ }^{a}$

\begin{tabular}{|c|c|c|c|}
\hline \multirow[b]{2}{*}{$\begin{array}{l}\text { Independent } \\
\text { Variable }\end{array}$} & \multicolumn{3}{|c|}{ Dependent Variable } \\
\hline & $\begin{array}{l}\ln \left(p f^{\prime p} n^{\prime}\right) \\
\text { full-time }\end{array}$ & $\begin{array}{l}\operatorname{In}\left(p_{p} p_{t i m e}^{\prime}\right)^{\prime} \\
\text { part }\end{array}$ & $\begin{array}{l}\left.\text { In ( } p u^{\prime p} n^{\prime}\right) \\
\text { unemployed }\end{array}$ \\
\hline \multirow[t]{2}{*}{ Intercept } & -2.591 & -1.423 & -6.302 \\
\hline & $(-2.87)$ & $(-3.04)$ & $(-11 \cdot 49)$ \\
\hline \multirow{2}{*}{$\begin{array}{l}\text { Full-time } \\
\text { Women's Wage }\end{array}$} & 0.207 & 0.014 & 0.130 \\
\hline & $(2.60)$ & $(0.37)$ & $(2.51)$ \\
\hline \multirow{2}{*}{$\begin{array}{l}\text { Part-time } \\
\text { Women's Wage }\end{array}$} & $-1 \cdot 125$ & 0.658 & -0.369 \\
\hline & $(-1.73)$ & $(1.98)$ & $(-0.92)$ \\
\hline \multirow[t]{2}{*}{ Men's Wage } & -1.134 & -1.023 & -0.717 \\
\hline & $(-1.78)$ & $(-3.11)$ & $(-1,70)$ \\
\hline \multirow[t]{2}{*}{ Unemployment } & -8.889 & -7.091 & 8.128 \\
\hline & $(-2.13)$ & $(-3.28)$ & $(3.41)$ \\
\hline \multirow[t]{2}{*}{ Women's Education } & -0.761 & -0.645 & -0.129 \\
\hline & $(-1.12)$ & $(-1.81)$ & $(-0.30)$ \\
\hline \multirow[t]{2}{*}{ Nursery/Day-Care } & 1.408 & 1.358 & 1.044 \\
\hline & $(3.02)$ & $(5.70)$ & $(3.53)$ \\
\hline \multirow[t]{2}{*}{ Industry Mix } & 0.278 & 1.544 & 0.138 \\
\hline & $(0.35)$ & $(3.86)$ & $(0.28)$ \\
\hline F-statistic & 31.40 & 39.96 & 21.99 \\
\hline$R$-Squared & 0.85 & 0.88 & 0.80 \\
\hline
\end{tabular}

Asymptotic t-ratio in parentheses.

The natural logarithm of the variable.

TABLE 2

Marginal Effects and Elasticities ${ }^{\mathbf{a}}$

\begin{tabular}{|c|c|c|c|}
\hline $\begin{array}{l}\text { Independent } \\
\text { Variable }\end{array}$ & full-time & ${ }_{\operatorname{part}}^{\mathrm{P}} \mathrm{P}_{\text {time }}$ & $\mathrm{P}_{\text {unemployed }}$ \\
\hline $\begin{array}{l}\text { Fuli-time } \\
\text { Women's Wage }\end{array}$ & $\begin{array}{l}0.01 E-1 \\
(0.15)\end{array}$ & $\begin{array}{l}-0.03 E-2 \\
(-0.04)\end{array}$ & $\begin{array}{l}0.01 E-3 \\
(0.08)\end{array}$ \\
\hline $\begin{array}{l}\text { Part-time } \\
\text { Women's Wage }\end{array}$ & $\begin{array}{c}-0.51 \\
(-1.00)\end{array}$ & $\begin{array}{c}0.37 \\
(0.79)\end{array}$ & $\begin{array}{l}-0.02 E-1 \\
(-0.24)\end{array}$ \\
\hline Men's W̧ages & $\begin{array}{l}-0.14 \\
(-0.62)\end{array}$ & $\begin{array}{l}-0.11 \\
(-0.51)\end{array}$ & $\begin{array}{l}-0.08 E-2 \\
(-0.20)\end{array}$ \\
\hline Unemployment & $\begin{array}{l}-1.29 \\
(-0.14)\end{array}$ & $\begin{array}{l}-0.77 \\
(-0.09)\end{array}$ & $\begin{array}{c}0.05 \\
(0.32)\end{array}$ \\
\hline Women's Education & $\begin{array}{l}-0.10 \\
(-0.21)\end{array}$ & $\begin{array}{l}-0.07 \\
(-0.16)\end{array}$ & $\begin{array}{l}-0.08 E-2 \\
(-0.10)\end{array}$ \\
\hline Nursery/Day-Care & $\begin{array}{c}0.19 \\
(0.50)\end{array}$ & $\begin{array}{l}0.16 \\
(0.46)\end{array}$ & $\begin{array}{l}0.01 E-1 \\
(0.25)\end{array}$ \\
\hline Industry Mix & $\begin{array}{l}-0.04 \\
(-0.07)\end{array}$ & $\begin{array}{l}0.25 \\
(0.53)\end{array}$ & $\begin{array}{l}-0.01 E-1 \\
(-0.13)\end{array}$ \\
\hline
\end{tabular}

These values are calculated based on the coefficients reported In Table 1. Estimated elasticities calculated at the sample means are in parentheses. 


\section{REFERENCES}

Cazn, Glen G., and Dooley, Martin D., "Estzmatzon of a Model of Labor Supply, Fertality, and wages of Married Women," Journal of Pollelcal Economy, Vol. 84 (August 1976): Pp. $\$ 179-5199$.

Dooley, Martin D., "Labor Supply and Fertility of Married Women: An Analysis wath Grouped and Individual Data from the 1970 U. S. Census," Journal of Human Resouxces, Vol. 17 (Fall 1982): pp. 499-532.

Furugorl, Tomoko, "Recent Changes in the Labor Force Behavior of Women in Japan: A Time-Series Analysis," Keio Economic Studies, vol. 17 (1980): pp. 51-69.

Hamilton, Jonathan H., "Fertility and Female Labor Force Participation in Japan," Paper presented at the Japan Economic Seminar at M.I.T., (March 1979).

Hill, M. Anne, "Female Labor Force Particapation in Developing and Developed Countries-Consideration of the Informal Sector," Review of Economics and Statistics, Vol. 65 (August 1983): pP. $459-68$.

-_. "Female Labor Force Participation In Japan: An Aggregate Model," Iournal of Human Besources, Vol. 19 (Spring 1984): Pp. $280-87$.

Japan, Department of Labor, Eujln Roudo Ne Iltsulou, Showa 57 Nenban (in Japanese), Tokyo: 1982.

- Department of Labor, Wage Census, Showa 55 Nenban (in Japanese), Tokyo: 1981.

- Department of Labor, White Papex of Labor, Showa 59 Nemban (in Japanese), Tokyo: 1984.

- Office of the Prime Minister, Bureau of Statistics, Japan Statistical Yearbook 1282, 32nd Amnual Edition, Tokyo: 1983.

- Office of the Prime Minister, Bureau of Statistics, 1980 Eopulataon Census of Iaran. Tokyo: 1983.

Statistics Bureau Prame Minister's Office, Annual Bepert on the Eimily Income and Expenditure Suyey 1280, Tokyo: 1981.

Killingsworth, Merk R., Lakor Suknly, New York: Cambradge Univ. Press, 1983.

Lunk, Charles R., and Sectle, Russell F., "A SimultaneousEquation Model of Labor Supply, Fertility and Earnings of Mirraed Women: The Case of Registered Nurses." Southern Ecournde Jovinal, Vol. 47 (April 1981): pp. 977-89. 
Long, James E., and Jones, Ethel B., "Part-Week Work by Marrıed Women," Southern Esenom Is Iournal, Vol. 46 (January 1980): PP. 716-25.

Morgenstern, Richard D., and Hamovitch, WIlliam, "Labor Supply of Married Women in Part-Time and Full-Time Occupations,"

Industrial and Labor Relations Review, Vol. 30 (October 1976): pp. 59-67.

Nagano, Hitoshi, "Major Influences on Changing Female Labor Supply," unpublished M.A. Thesis, Aoyama Gakuln UnIversity, Japan, 1980 (in Japanese).

Nakamura, Alice, and Nakamura, Masao, "Part-Time and Full-Tıme Work Behavior of Married Women: A Model with a Doubly Truncated Dependent Varlable," Canadian Journal of Economiss, Vol. 16 (May 1983): pp. 229-57.

Schultz, T. Paul, "The Influence of Fertility on Labor Supply of Married Women: Simultaneous Equation Estimates," In Donald G. Ehrenberd, ed., Researcb in Labor Economics, Vol. 2, Connecticut: JAI Press, 1978, pp. 273-351.

Shimada, Haruo, et. al., A Study of Curcent Laber Market Structure, Tokyo: Japan Institute of Labor, 1981 (in Japanese).

, and Higuchi, Yoshio, "An Analysis of Trends in Female Labor Force Particlpation in Japan," Iournal ef Labor Economics, Vol. 3, (January 1985): pp. S355-S374.

Theil, Henri, Princleles of Econometrics, New York: John Wiley and Sons, 1971. 